\title{
'There Are No Other Options?': Rwandan Gender Norms and Family Planning in Historical Perspective
}

\author{
ERIN JESSEE * \\ 4092 University Gardens, History, University of Glasgow, Glasgow G12 8QH, Scotland
}

\begin{abstract}
This article surveys the evolution of Rwandan family planning practices from the nation's mythico-historical origins to the present. Rwanda is typically regarded as a patriarchal society in which Rwandan women have, throughout history, endured limited rights and opportunities. However, oral traditions narrated by twentieth-century Rwandan historians, storytellers and related experts, and interpreted by the scholars and missionaries who lived in Rwanda during the nation's colonial period, suggest that gender norms in Rwanda were more complicated. Shifting practices related to family planning - particularly access to contraception, abortion, vasectomies and related strategies - are but one arena in which this becomes evident, suggesting that women's roles within their families and communities could be more diverse than the historiography's narrow focus on women as wives and mothers currently allows. Drawing upon a range of colonial-era oral traditions and interviews conducted with Rwandans since 2007, I argue that Rwandan women - while under significant social pressure to become wives and mothers throughout the nation's past - did find ways to exert agency within and beyond these roles. I further maintain that understanding historical approaches to family planning in Rwanda is essential for informing present-day policy debates in Rwanda aimed at promoting gender equality, and in particular for ensuring women's rights and access to adequate healthcare are being upheld.
\end{abstract}

Keywords: Rwanda, Family planning, Gender norms, Religion, Colonisation

Lord Jesus, it is you who formed our country. You have given us a long line of kings to govern in your place, even though we did not know you. When the time fixed by your Providence had arrived, You have been made known. You have sent us your apostles; they have opened to us the light . . Now that we know you, we recognize publicly that you are our Lord and our King. ${ }^{1}$

With these words, delivered to the nation in 1946, Rwanda's Mwami (king) Mutara Rudahigwa (r. 1931-59) established Rwanda as the first Catholic kingdom in the heart of Africa. A descendant of a line of abami (kings) descended from the powerful Abanyiginya clan, Rudahigwa's declaration represented a marked cultural transformation for the nation, whose citizens previously relied upon the abami - each of whom was considered a conduit

* Email address for correspondence: erin.jessee@glasgow.ac.uk

${ }^{1}$ Cited in J.J. Carney, Rwanda Before the Genocide: Catholic Politics and Ethnic Discourse in the Late Colonial Era (Oxford: Oxford University Press, 2014), 40. 
to Imana (god) - to ensure their political and spiritual well-being. The mwami and his Umugabekazi (Queen Mother), abamikazi (queens) and abwiru (court ritualists) performed rituals associated with the indigenous religion, kubandwa, to negotiate the well-being of their people. ${ }^{2}$

Rwanda's dedication to the Catholic Church was the gradual outcome of a concentrated effort on the part of missionaries associated with La société des missionnaires d'Afrique (also known as the White Fathers or Pères Blancs). The White Fathers arrived in Rwanda during the German colonial period from 1895 to 1916 . They established their first missions in 1900 at Save, Mibirizi, Zaza, Nyundo, and Rwaza, all of which were strategically placed at a distance from then-Mwami Yuhi Musinga's royal court at Nyanza, but close enough that they were still within the court's 'sphere of influence'. ${ }^{3}$ Their initial conversion efforts met with limited success: by 1914, they had only baptised an estimated 10000 Rwandans, mostly among the rural poor. ${ }^{4}$ Indeed, missionaries' efforts only began to show signs of success after the Belgians took control of Rwanda in 1916, and particularly after their colonial administration deposed Musinga in 1931 for refusing to convert to Christianity and otherwise resisting Belgian interests in the region. ${ }^{5}$ Faced with their mwami's deposition, the court notables embraced the Belgians' chosen successor - Musinga's son, Rudahigwa - who had been secretly taking instruction from the White Fathers and seemed more amenable to Belgian interests. As Rudahigwa's conversion progressed over the next decade, many Rwandans - both court notables and civilians alike - followed suit. As of December 2018, an estimated forty-four per cent of Rwandans identified as Catholic, making it the second most prominent religion in the country. ${ }^{6}$

Much of the historiography on colonial Rwanda focuses on the upheaval that Rwanda's gradual conversation to Catholicism created among court notables who served under Musinga and Rudahigwa as they struggled to maintain their indigenous religious practices. ${ }^{7}$ Less commonly addressed, however, are the challenges that conversion posed for ordinary Rwandans, many of whom undoubtedly found social bonds within their families and communities profoundly altered, and their indigenous spiritual beliefs ostracised by the missionaries and their more zealous converts as they encouraged Rwandans' adherence to Catholicism and European values. But precisely how the spread

\footnotetext{
${ }^{2}$ Christopher Taylor, Milk, Honey and Money: Changing Concepts in Rwandan Healing (Washington: Smithsonian Books, 1992), 66; Jan Vansina, Antecedents to Modern Rwanda: The Nyiginya Kingdom (Madison: University of Wisconsin Press, 2005), 39. See also Iris Berger, The Kubandwa Religious Complex of Interlacustrine East Africa: An Historical Study (Madison: University of Wisconsin Press, 1973); Luc de Heusch, 'Mythe et société féodale: Le culte du kubandwa dans le Rwanda traditionnel', Pourquoi l'éspouser? (1971), 205-25; and Alexis Kagame, Un abrégé de l'ethno-histoire du Rwanda (Butare: Editions universitaires du Rwanda, 1972).

${ }^{3}$ Carney, op. cit. (note 1), 25.

${ }^{4}$ Carney notes that the White Fathers regarded this number as disappointing, compared to the estimated 100000 Ugandans who had converted to Catholicism by this time, op. cit. (note 1), 28.

5 Alison Des Forges, Defeat is the Only Bad News: Rwanda Under Musinga, 1896-1931 (Madison: University of Wisconsin Press, 2011), 237-40.

${ }^{6}$ Central Intelligence Agency, 'The World Factbook: Rwanda', updated 27 December 2018, https://www.cia.g ov/library/publications/the-world-factbook/geos/rw.html. The Catholic Church was more prominent prior to the 1994 genocide, in which an estimated 800000 Tutsi civilians were murdered by Hutu Power extremists. However, its Rwandan leadership's widespread complicity in the genocide prompted many Rwandans to leave the church. Today, Protestant Christians make up Rwanda's largest religious community. Timothy Longman, Christianity and Genocide in Rwanda (Cambridge: Cambridge University Press, 2009).

${ }^{7}$ See, for example, Carney, op. cit. (note 1); Des Forges, op. cit. (note 5); Longman, op. cit. (note 6); Catharine Newbury, The Cohesion of Oppression: Citizenship and Ethnicity in Rwanda, 1860-1960 (New York: Columbia University Press, 1988).
} 
of Catholicism and related values impacted ordinary Rwandans' lives in the early to midtwentieth century has not been thoroughly addressed by historians and related scholars. ${ }^{8}$

To begin addressing this gap, this article explores the intersections between Rwandan gender norms and what in Euro-American Anglophone terms is called 'family planning', and in Kinyarwanda is referred to as kuboneza urubyaro ('to control birth'), prior to and during the colonisation of Rwanda. I begin with a critical overview of the sources and methodology that underpins this article. I then discuss the value of children in early Rwandan history as represented in one of Rwanda's most popular origin myths, and its relevance for facilitating a more nuanced understanding of early Rwandan gender norms. Next, I consider the growing influence of Catholicism during the Belgian colonial period and the impact this had on people's attitudes toward family planning, among other facets of their lives. I then discuss how the respective governments associated with the First (196273) and Second (1973-94) Hutu Republics approached the subject of family planning. Finally, I analyse the present situation in Rwanda. As one of the most densely populated nations in the world, and with an estimated sixty per cent of its population under the age of twenty-five, the current government has introduced various laws and policies to make family planning education, medications and procedures readily available to the public, and to 'sensitise' the population to their necessity. These policies are taking shape in tandem with the government's many gender equality initiatives, which seek to empower women in politics and in their everyday lives, and for which the post-genocide government is lauded internationally. I argue that while the Rwandan government and the many Rwandan citizens are broadly supportive of gender equality, family planning initiatives are often regarded with suspicion for reasons that cannot be solely attributed to people's adherence to Catholic values. Indeed, a key challenge facing the state's efforts to empower women relates to the ongoing social pressures endured by many Rwandan women - and by extension, their husbands - to bear as many children as possible.

\section{On Methodology and Underlying Sources}

This article emerges from the margins of various oral historical and ethnographic projects I have undertaken in Rwanda since 2007. ${ }^{9}$ While family planning has never been the focus of my research in Rwanda, my interest in this topic was peaked by the countless conversations I have had with Rwandans over the years who found my decision not to have children - as an adult in a long-term committed relationship with a man whom many of her collaborators and research participants have met over the years unimaginable, given the importance placed on having children in modern Rwanda. Perhaps for this reason, the subject of children and family planning has often been raised by the gatekeepers, collaborators, research assistants and participants with whom I have worked, both informally - in the context of casual conversations - and formally - in the context of ethnographic encounters and recorded interviews. Throughout these projects, I have worked closely with at least one of eight research assistants, who have provided simultaneous translation of conversations and interviews from Kinyarwanda to English,

\footnotetext{
${ }^{8}$ An important exception to this statement is the subject of the introduction of ethnicity by Europeans, which will be addressed in greater detail below, and other topics that relate to the roots of the 1994 genocide.

${ }^{9}$ I am grateful to Canada's Social Science and Humanities Research Council for funding my initial doctoral and postdoctoral research in Rwanda, as well as the Centre for International Governance Innovation's Africa Initiative, the Carnegie Trust and the Royal Society of Edinburgh for having allowed me to continue conducting historical research in the country. Likewise, this article would not have been possible without the incredible support of my Rwanda-based research assistants, and the valuable feedback I received from Laura Kelly, Agata Ignaciuk and two anonymous reviewers.
} 
where necessary, and similarly helped me produce verbatim transcripts in English of recorded interviews and related data. ${ }^{10}$ To inform my understanding of these fieldwork encounters, in this article I bring these sources into conversation with select archived ibitekerezo (oral traditions) and related colonial-era sources in which the value of children in Rwandan culture is highlighted, as well as other archival sources that speak to public debates around family planning since Rwanda's independence in 1962.

The ibitekerezo and related colonial-era sources that are analysed here are taken from several scholars' collections. My primary source for ibitekerezo is the collection of historian Jan Vansina (the Vansina Collection). Between 1958 and 1960 he documented Rwandan oral traditions as they were told to him by court notables, and subsequently archived them at the Royal Central African Museum in Tervuren, Belgium, and the University of Chicago in the United States. ${ }^{11}$ Since 2015, Sylvere Mwizerwa and I have worked on translating the Vansina Collection, and in 2017 we welcomed Jerome Irankunda to our team. We have prioritised the translation of ibitekerezo that speaks to the experiences of Rwandan men and women from a range of backgrounds - not just the political elites that Vansina focused on in his research. However, most of the people whose lives have been commemorated in these ibitekerezo were, for varying reasons, considered notable because of their interactions with the court at different points in the nation's history. We make every effort to preserve, as much as is possible, the orality and original meaning of these ibitekerezo. That said, the highly symbolic and at times antiquated Kinyarwanda presented in these sources, and the lack of annotation related to changes in tone, rhythm of speech and shifts in emotion, among other meaningful forms of communication, means that our ability to fully understand the nuances of these sources is likely compromised.

I have also drawn upon historian Rose-Marie Mukarutabana's collection from her now-defunct website 'Gakondo', which contained her translations of the ibitekerezo documented by historian Alexis Kagame, and linguists André Coupez and Thomas Kamanzi, among others. ${ }^{12}$ Mukarutabana is an expert on Rwandan language, history and cultural heritage, who has advised the work of historians Alison Des Forges, Catharine Newbury, David Newbury and countless other scholars since the 1960s. It is her version of the 'Myth of Kigwa' that features in this article, as to date it remains the most comprehensive version I have been able to find in Kinyarwanda, French and English. Finally, Mwizerwa, Irankunda and I have surveyed ongoing conversations in the Rwandan media in Kinyarwanda and English that pertain to changing family planning policies and practices.

The resulting data are complex and at times contradictory, requiring careful triangulation and contextualisation to identify relevant themes and transgressions of importance for understanding early Rwandan history. There are, as well, lingering gaps in the historical record, which, given the sporadic nature of the archival materials available on Rwanda and, of particular relevance to this article, the taboo nature of some family

\footnotetext{
10 The research assistants and research participants associated with my earlier fieldwork in Rwanda have chosen to remain anonymous in the outcomes I produce associated with these research projects. Below, however, I use with their consent - the real names of the research assistants who have helped with the translation of the media articles I rely upon in this article.

${ }^{11}$ I am grateful to historian Sarah Watkins for kindly sharing with me her scans of the Vansina Collection. For more information, see The Vansina Collection, Ibitéekerezo: Historical Narratives from Rwanda: A Collection of Texts and Translations, 1957-61 (Chicago: CRL-CAMP Department of Photoduplication, University of Chicago Library, 1973).

${ }^{12}$ Rose-Marie Mukarutabana, 'Gakondo', http://www.dlblanc.com/Gakondo/en/Myths/Kigwa.php (archived).
} 
planning methods, may be impossible to fill. Of equal importance is the realisation that many aspects of Rwandan history have been politicised in different ways and at different points in the nation's past.

The aforementioned ibitekerezo, for example, were one of four different kinds of oral traditions through which Rwandan history related to the Nyiginya kingdom was preserved and disseminated. ${ }^{13}$ They were memorised and performed by historians and storytellers affiliated with the court at social events as a means of entertaining and educating court notables and the public. In this manner, court officials could influence how civilians perceived the kingdom's past, present and future. It is likely that with each new mwami, the ibitekerezo pertaining to previous abami and their courts were altered to reinforce the new mwami's vision for the kingdom and perspective on his predecessors. Certainly, in Rwanda's recent history, the German (1895-1916) and Belgian (1916-62) colonial administrations, and - following the nation's independence in 1962 - the regimes of Presidents Grégoire Kayibanda (1962-73) and Juvénal Habyarimana (1973-94) have reinterpreted Rwanda's monarchical past to suit their particular political platforms. Elsewhere, Sarah Watkins and I have argued that many Rwandans are still influenced by these competing interpretations of the monarchy: generally, the stories they recall and the value they attributed to the monarchy as a whole are heavily influenced by their personal political values, among other facets of their individual identities. ${ }^{14}$

This phenomenon of re-envisioning the past in accordance with shifts in a nation's political sphere is by no means unique to Rwanda. Nonetheless, historians and related practitioners have developed a specific theoretical framework for addressing the complications that emerge from the politicisation of the past in Rwanda and elsewhere in the Great Lakes region of Africa. This framework is centred on political scientist Liisa Malkki's concept of the 'mythico-history', which she introduced to encapsulate those narratives that constitute 'a subversive recasting and reinterpretation of [the past] in fundamentally moral terms' ${ }^{15}$ This concept was grounded in her research among ethnic Hutu refugees who were living in Tanzania in the 1990s after fleeing the 1972 genocide in neighbouring Burundi. ${ }^{16}$ She found these refugees had developed an extreme form of Hutu nationalism that shaped how they spoke about Burundi's past and their forced

\footnotetext{
13 The Nyiginya kingdom dominated the region starting in approximately the sixteenth century until 1962. The other three kinds of oral traditions maintained by its courts were the ubwiru (rituals), ubucurabwange (dynastic lists) and ibisigo (dynastic poetry). Jan Vansina, 'Historical tales (Ibitéekerezo) and the History of Rwanda', History in Africa, 27 (2000), 378-9.

${ }^{14}$ Erin Jessee and Sarah Watkins, 'Good Kings, Bloody Tyrants and Everything in between: Representations of the Monarchy in Post-Genocide Rwanda', History in Africa, 41 (2014), 35-62.

${ }^{15}$ Liisa Malkki, Purity and Exile: Violence, Memory and National Cosmology Among Hutu Refugees in Tanzania (Chicago: Chicago University Press, 1995), 54. See also, Yolande Bouka, '(Oral) History of Violence: Conflicting Narratives in Post-Genocide Rwanda,' Oral History Forum d'Histoire Orale, 33 (2013), 7; Jennie Burnet, 'Whose genocide? Whose truth? Representations of victim and perpetrator in Rwanda', in A. Hinton and K. O’Neill (eds), Genocide: Truth, Memory and Representation (Durham: Duke University Press, 2009), 96; Erin Jessee, Negotiating Genocide in Rwanda: The Politics of History (Cham: Palgrave Macmillan, 2017), 119-20; Ibid., 37-8; Elizabeth King, 'From Data Problems to Data Points: Challenges and Opportunities of Research in Postgenocide Rwanda', African Studies Review, 52, 3 (2009), 127-48; and Marc Sommers, 'Review of Liisa Malkki, Purity and Exile: Violence, Memory and National Cosmology Among Hutu Refugees in Tazania', American Anthropologist, 99, 1 (1997), 218.

${ }^{16}$ Malkki, Ibid., 54. For more on the 1972 genocide in Burundi, see, for example, René Lemarchand, 'Burundi 1972: Genocide denied, revised and remembered', in R. Lemarchand (ed.), Forgotten Genocides: Oblivion, Denial and Memory (Philadelphia: University of Pennsylvania Press, 2011), 37-50.
} 
migration to Tanzania: one that demonised the allegedly 'foreign' and inherently 'evil' Tutsi 'trickster[s]' who had perpetrated the genocide. ${ }^{17}$

This trope relied on the long-discredited 'Hamitic hypothesis' introduced to the region by European social scientists in the early 1900s, which wrongly maintained that the predominantly pastoralist Tutsi - by virtue of their alleged superior beauty and intellect, and lighter skin - were the semi-Caucasian descendants of the biblical figure Ham, and therefore were the natural rulers compared to their allegedly 'pure African' and predominantly agriculturalist Hutu and hunter-gatherer Twa compatriots. ${ }^{18}$ The German and Belgian colonial administrations used the Hamitic hypothesis to justify their preferential treatment of the Tutsi. Further complicating matters, in the 1930s the Belgians introduced identity cards that included people's ethnicity as either Hutu, Tutsi or Twa. From this point forward, a person's socio-economic status was conflated with their ethnic identity, was inherited patrilineally, and took on increasing social salience, gradually subsuming other previously more important markers of identity related to a person's lineage, clan, hill and region of origin, for example. ${ }^{19}$ In the process, many Rwandans in the region internalised a particularly toxic understanding of what it meant to be Hutu, Tutsi or Twa that set the stage for decades of ethnic tension and periodic political violence that was often justified by different regimes in mythico-historical terms.

The prevalence of mythico-historical interpretations of the past, however, is by no means unique to discussions of race and ethnicity in Rwanda. Indeed, it is a valuable lens for considering many facets of historical and political inquiry on Rwanda due to its ability to provide insight on the meaning that the past has for people in the present. It provides a starting point for discussing competing perspectives and experiences, as well as the less-often addressed lies, rumours, evasions and silences - among other often overlooked forms of metadata - that political scientist Lee Ann Fujii argues can also be an important source of information. ${ }^{20}$ This is true when applied to the oral traditions and life histories documented by scholars in the latter years of Rwanda's colonial period, as well as more recently documented historical sources.

\section{The Myth of Kigwa: Early Gender Norms and the Value of Children in Rwandan Culture}

The 'Myth of Kigwa' is a popular and important origin myth that offers a good starting point for thinking about the challenges that surround family planning initiatives in modern Rwanda. Mukarutabana's translation - one of several possible iterations that have survived in the present - begins with Gasani, one of the wives of Nkuba, the King of Heaven, lamenting her inability to have more children, leaving her palace 'empty and silent'. ${ }^{21} \mathrm{~A}$ diviner named Imhamvu visited her, prophesied that Gasani could soon give birth to a baby boy and offered to help if Gasani would make her part of her retinue. Gasani agreed, and

\footnotetext{
${ }^{17}$ Malkki, op. cit. (note 15), 72.

${ }^{18}$ Malkki, op. cit. (note 15), 68. British physician and ethnologist Charles Seligman was a key proponent of the Hamitic hypothesis. His 1930 book, Races of Africa, distinguishes between Hamite pastoralists who were of European descent and 'two other African stocks, the Negro and the Bushman'. Charles Seligman, Races of Africa (Oxford: Oxford University Press, 1930), 96. For additional information, see Edith Sanders, 'The Hamitic Hypothesis: Its Origin and Functions in Time Perspective', Journal of African History, 10, 4 (1969), 521-32.

${ }^{19}$ Newbury, op. cit. (note 7), 193.

${ }^{20}$ Lee Ann Fujii, 'Shades of Truth and Lies: Interpreting Testimonies of War and Violence', Journal of Peace Research, 47, 2 (2010), 231-41.

${ }^{21}$ There is no mention of how many children Gasani had previously. Mukarutabana, op. cit. (note 12).
} 
so Imhamvu instructed her to take the heart from a bull that Nkuba had recently sacrificed to decide who should succeed him as king, and place the heart in a milk jug made from the sacred umurinzi ('protector') tree. ${ }^{22}$ Imhamvu instructed her to add warm milk to the jug each morning and evening, and nine months later Gasani opened to the jug to find a baby boy. Gasani named him Sabizeze ('a gift that results from god's favour'), and his 'birth' was celebrated throughout the kingdom. Gasani's status at court was immediately enhanced, even as Nkuba - who had been away at war, fighting to expand his kingdom's borders - doubted that Sabizeze was his biological son and threatened to kill him. Gasani and Imhamvu subsequently conspired with the help of besotted court notables to hide Sabizeze - a rare and dangerous act of defiance against their mwami. ${ }^{23}$

The 'Myth of Kigwa' offers several insights of importance for understanding early Rwandan gender norms. At present, interdisciplinary scholarship tends to stress the patriarchal nature of Rwandan society, seemingly since time immemorial. ${ }^{24}$ This consensus is largely informed by observations documented by foreign and Rwandan researchers who have studied the nation since its independence in 1962, and who have accurately commented upon the strict gender divisions that dictated contemporary Rwandan men and women's lives. However, scholars actually know little about preindependence gender norms: historians, in particular, have largely overlooked Rwandan women in their analysis of early Rwandan history. ${ }^{25}$ For example, in Vansina's study of the Nyiginya kingdom, Antecedents to Modern Rwanda, he briefly summarises women's status as 'complex and variable' and determined by the social position of the men in their lives, their marital status and age and their ability to raise well-mannered children. ${ }^{26}$

The 'Myth of Kigwa' offers insight into precisely how one elite Rwandan woman improved her social status by having children, arguably providing a model for subsequent generations. As Sabizeze grew older, he became renowned for his exceptional beauty and kindness, and so Gasani's status and power at court grew. ${ }^{27}$ This supports Vansina's conclusion that while men could gain social status in a variety of ways - from being wise advisors, powerful warriors or having great wealth, for example - a primary way

\footnotetext{
22 The narrative mentions that prior to being sacrificed, the bull was fed 'royal saliva', which is often interpreted as meaning the mwami's semen. This may explain why ultimately Gasani did not see Sabizeze as illegitimate, and why as the child grew older he was said to look more like Nkuba. Mukarutabana, op. cit. (note 12).

23 The mwami had the power to execute people who displeased him, and so resistance to the mwami's authority was rare and required exceptional provocation. Vansina, op. cit. (note 2), 89-90.

${ }^{24}$ See, for example, Sara Brown's recent discussion of pre-genocide Rwanda as characterised by 'deeply entrenched patriarchal systems' in which 'Rwanda's women were hard pressed for a space to exercise agency'. Sara Brown, Gender and the Genocide in Rwanda: Women as Rescuers and Perpetrators (London: Routledge, 2018), 33; and Sara Brown, 'Reshaping Gender Norms in Post-Genocide Rwanda', Genocide Studies International, 10, 2 (2016), 233.

25 There are a few exceptions: Des Forges, Vansina and historian Sarah Watkins have written about abagabekazi who ruled as equals alongside their sons when they became kings during the Nyiginya kingdom. Des Forges, op. cit. (note 5); Vansina, op. cit. (note 2); and Sarah Watkins, 'Iron Mothers and Warrior Lovers: Intimacy, Power and the State in the Nyiginya Kingdom, 1796-1913'.

${ }^{26}$ Vansina, op. cit. (note 2), 31.

27 As elite men could have multiple wives, it was typically the husband's favourite wife who could exercise the most power within their communities. In the case of abamikazi (queens), their political power rested on the abami deciding not only that they were their favourite wife, but that they should be named umugabekazi (Queen Mother) to the son whom their husband wanted to succeed him - a position that allowed them to share power equally with their husband's successor. In most cases, the abamikazi and abagabekazi (queen mothers) were descendants of three powerful matridynastic clans, the Abega, the Abakono and the Abasinga, which ensured that these clans shared monarchical power with the otherwise dominant Abanyiginya clan. However, Rwandans often say that all beautiful women belonged to the king, regardless of their clan.
} 
that women could enhance their social status was to raise beautiful, intelligent and wellmannered children, particularly sons. ${ }^{28}$

However, the ibitekerezo also indicates that women - particularly elites - may have had greater agency in the past than the historiography on Rwanda typically acknowledges. Gasani had the power to get pregnant by means other than direct intercourse with her husband, and furthermore was able to draw upon contemporary spiritual beliefs to reinforce the validity of doing so. This is evident in the court notables' immediate acceptance of Sabizeze, rather than questioning his legitimacy or Gasani's loyalty to Nkuba. Furthermore, once Sabizeze was born, Gasani's status as his mother made it possible for her to rally supporters within the court to help her thwart Nkuba's plan to kill his 'illegitimate' son, which - as her husband and king - he had every right to demand. While these factors do not completely contradict the prospect that the Nyiginya kingdom - and Nkuba's mythical reign in particular - was patriarchal, they do suggest that greater research is needed to fully understand the nuances of early Rwandan gender norms.

Of similar value, the 'Myth of Kigwa' also highlights the importance of children in Rwandan culture at least since the early twentieth century, if not earlier. Gasani went to great lengths to have more children, potentially at great risk to her marriage and life. As Nkuba plotted to kill Sabizeze, Gasani and Imhamvu hid him in defiance of their mwami. However, it was Sabizeze's beauty and good manners that ultimately saved his life: in response to the stories that circulated about the child, a group of elders finally asked for an audience. Upon seeing that Sabizeze looked like Nkuba, they convinced the king to see the child. This part of the story ends happily: 'As soon as he set eyes on little Sabizeze, all desire of killing him suddenly left the King, and instead, he recognised him, took him into his arms, lifted him high up, then set him on his knee, and gave him a name: Imana, Divinity'.29

But while the 'Myth of Kigwa' demonstrates at the immense value Rwandans associated with having children, potentially since the earliest days of the kingdom, it is important to note that the privilege of having children was reserved for people who were married. In interviews I have conducted across Rwanda since 2007, elders acknowledged a tradition they associated with the nation's pre-Christian past whereby young unmarried girls who became pregnant would be abandoned on a small island in Lake Kivu known as Kabakobwa. Elders spoke of this practice as a punishment necessitated because a pregnant girl had denied her parents a good dowry. ${ }^{30}$ As a result of a taboo that prohibited harming children, the offending girl could not be directly harmed by her parents or her community,

\footnotetext{
${ }^{28}$ It is difficult to reconstruct what precisely Vansina and other historians who work on early Rwandan history mean by phrases like 'well-mannered children'. However, in modern Rwanda, great value is placed on raising children who are quiet, do not cry or complain too much, contribute to the family by performing chores around the home, and treat their elders with respect.

${ }^{29}$ Mukarutabana, op. cit. (note 12). The story goes on to tell of how Sabizeze later overheard Gasani talking about how he was conceived, which made him very angry, prompting him to reject Gasani and leave heaven, taking with him two siblings, fire, and various domesticated animals to help them in their new life on Earth. The remainder of the story tells of how they settled in what is today northwestern Rwanda among people of the Abazigaba clan, and ultimately gave rise to the Nyiginya kingdom. Sabizeze became known as Kigwa (meaning 'fallen') and his descendants gave rise to the Abanyiginya clan, while his siblings gave rise to the Abega, Abaha and Abakono clans.

${ }^{30}$ In ideal circumstances, the father of a beautiful young girl would be given a cow - a highly valued status symbol due to its ability to produce milk and thereby enhance the wealth of the recipient - by the father of the intended groom as a form of dowry. There was no punishment for the boy or man responsible for getting the young girl pregnant.
} 
nor could they harm her unborn child. However, by abandoning her on Kabakobwa, it was expected that the girl would die from exposure, starvation or an attack by a wild animal. ${ }^{31}$ That said, some elders argued that these abandoned girls likely survived their sentences to live full lives in the neighbouring Congo. For example, one elderly woman who lived near Kabakobwa noted that a girl who was abandoned in this manner could 'be eaten by snakes or some other wild animals, unless she was lucky enough to be found by Congolese men, who would take her'. Many Rwandans believe that throughout Rwandan history, poor Congolese men - drawn in by the allegedly superior beauty of Rwandan women whom they could otherwise never afford to marry - frequently visited the island in the hope of finding a free bride. They argued that even with the costs associated with taking in another man's baby, Congolese men would see their new Rwandan bride as a good deal. ${ }^{32}$

Because of the broader stigma and potential for exile or death facing young unmarried girls who became pregnant, it is likely that Rwandans had natural methods for ending unwanted pregnancies. Such practices are not discussed overtly in the ibitekerezo and related sources that I have analysed to date, though this is unsurprising as these accounts are often highly euphemistic in discussing intimate or taboo matters. However, women frequently appear alongside men as spiritual leaders and healers who used their connection to mystical powers, and their knowledge of ritually significant animals, plants and trees, to divine the future, appease the angry abazimu (spirits) of neglected ancestors and heal their loved ones or inflict suffering upon their perceived enemies.

A classic example of this appears in an ibitekerezo about the battle between Umwamikazi Nyirabiyoro - a queen who commanded many armies in Mubari (northwestern Rwanda) - and Mwami Kigeri Ndabarasa (c.1708-41). ${ }^{33}$ Ndabarasa wanted to incorporate her lands into his kingdom, but Nyirabiyoro was a powerful sorceress with her own political ambitions. When confronted by Ndabarasa, Nyirabiyoro used a range of spells and poisons to bewitch him in an attempt to prevent him from overpowering her, including her own vaginal fluids and urine. Ndabarasa allegedly had powerful magic at his disposal as well, though, and so he defeated her. That night, Ndabarasa's soldiers killed Nyirabiyoro for disrespecting their mwami. To appease her spirit, which Ndabarasa anticipated would be vengeful due to her violent death, he arranged for a male goat to be sacrificed and placed between her legs before she was buried - an act that was simultaneously symbolically reminiscent of childbirth and of blocking the physical source of her spiritual power. This seemingly unusual burial ritual was intended to prevent Nyirabiyoro's spirit from attacking Ndabarasa from the afterlife.

In interviews and casual conversations since 2007, many Rwandans have recalled that women and girls could have used many different medical plants in the past to cause miscarriages that were part of a broader specialist practice of curing physical and spiritual illnesses. ${ }^{34}$ I have never encountered anyone, however, who would admit to having used these medicines or to knowing the specific details of how they worked. People frequently noted that while such practices were undoubtedly widespread, they were highly taboo as children are 'treasures' that enrich their family and should be protected. Among the more

\footnotetext{
31 Jessee, op. cit. (note 15), 101-2.

32 Indeed, some Rwandans claim that this explains the origins of the Banyamulenge people in the eastern regions of the Democratic Republic of the Congo (DRC), who are Kinyarwanda-speaking and predominantly Tutsi pastoralists.

${ }^{33}$ H Kigeri Ndabarasa file \#10, The Vansina Collection. This is one of several ibitéekerezo related to Nyirabiyoro that can be found in the Vansina Collection.

${ }^{34}$ See, for example, Taylor, op. cit. (note 2).
} 
religious - most frequently, Catholic or Evangelist Christian - Rwandans I interviewed, a common response was that children were a 'gift from God' and, as such, abortion (gukuromo inda) was a sin.

Where people acknowledged the possibility that these practices had been used in the past, they were quick to associate them with the dark craft of abarozi (poisoners) and other 'evil' specialists who, it seems, were not part of everyday Rwandan society and far removed from the more positively regarded spiritual leaders, healers and diviners associated with kubandwa and other indigenous religious practices. One elderly Rwandan woman I interviewed, who had served her community as an imandwa (initiate of kubandwa), noted that imandwa were forbidden to provide abortions 'as it was taboo to work backwards', meaning to end a life. However, she acknowledged that 'imandwa were sometimes asked to spiritually fight abarozi though, to prevent a woman from having miscarriages'.

\section{The Decline of the Monarchy and the Rise of Christianity in Rwanda}

For many Rwandans, the decline of the monarchy - beginning with Musinga's deposition in 1931 - was the point when Catholic and European values became more prevalent in their society. For rituals to be successful, kubandwa required a legitimate monarch who, as a direct conduit to Imana, would perform - sometimes alongside court notables or citizens, and other times in relative secrecy - the rituals that enabled the well-being of the kingdom. ${ }^{35}$ Musinga's deposition by the Belgians demonstrated to many adherents of kubandwa that the colonisers' God was more powerful than Imana. Indeed, several elderly Rwandans I interviewed noted that Musinga's deposition in 1931 caused turmoil among their communities, prompting many once-devout followers of kubandwa to convert to Christianity. Among historians and related scholars, the three years following Musinga's deposition has been termed 'the Tutsi tornade', due to the estimated 200000 elites and peasants - many of whom had previously been loyal to the monarchy and followers of kubandwa and other indigenous religions - who converted to Catholicism. ${ }^{36}$

Musinga's appointed successor, Rudahigwa, was appointed by the Belgian colonial administration without the approval of the abiru (court ritualists). Rudahigwa had converted to Catholicism and was generally seen as supportive to Belgian interests, prompting him to become known as 'the Mwami of the Whites' ${ }^{37}$ For some Rwandans, his authority was undermined by the fact that Musinga still lived and the abiru had not approved his succession, as well as Rudahigwa's refusal to perform rituals associated with kubandwa, which by this point was widely condemned by the White Fathers as a form of Satanism. ${ }^{38}$ But as Rudahigwa's new faith became more visible, and with his decision to dedicate Rwanda to Christ the King in 1946, Rwandans increasingly converted to Catholicism. In some cases, they merged Catholic beliefs and rituals with kubandwa and other indigenous religions, while others abandoned their indigenous religious beliefs completely. By the time the monarchy was dissolved and Rwandan independence was achieved in 1962, kubandwa had become rare and its remaining followers were ostracised by the White Fathers and Rwandan converts alike, at least in public.

\footnotetext{
${ }^{35}$ Indeed, Watkins notes that the mwami did not enjoy absolute power, and was under constant pressure to perform rituals to ensure the prosperity of his people and their cattle, and demonstrate his legitimacy. Watkins, op. cit. (note 25), 76.

${ }^{36}$ Carney, op. cit. (note 1); and Longman, op. cit. (note 6).

${ }^{37}$ Des Forges, op. cit. (note 5), 241.

${ }^{38}$ Des Forges, op. cit. (note 5), 241-2.
} 
This period of religious transformation had a dramatic impact on women's opportunities for social and political advancement, though once again the historiography on this period is limited. Anthropologist Helen Codere's The Biography of an African Society: Rwanda 1900-1960 represents a rare example whereby the life histories of women from different social backgrounds during Rwanda's colonial period are considered alongside that of men. In the process, she documents a period of heightened economic hardship and social stigma for women. While she notes that gender division of labour and the emphasis on Rwandan women being good wives and mothers was well-established prior to independence, she observed that as Rwandan men became 'Europeanized men in European occupations', Rwandan women, regardless of ethnicity or socio-economic status, faced heightened economic hardship and social stigma. ${ }^{39}$ The Rwandan people's conversion to Catholicism and the adoption of related European values meant that Rwandan women who had exercised power as spiritual leaders prior to colonisation had few equivalent opportunities for advancement within the new Christian religious communities that took shape. ${ }^{40}$ Women who had previously served as powerful imandwa gradually had to content themselves with being wives and mothers, as they could no longer practice kubandwa in public without being condemned as 'devil worshippers'.

Politically prominent women's status was similarly affected. For example, Musinga's umugabekazi, the notorious Nyirayuhi Kanjogera, and her successor, Nyiramavugo Kankazi, increasingly took a secondary role to their sons in ruling the kingdom. ${ }^{41}$ This represented a marked shift in monarchical leadership, which previously had been designed to ensure power-sharing between the Abanyiginya and the powerful matridynastic clans. But it arguably transformed the court into a more patriarchal institution that was better suited to the needs of the European colonisers. This transformation was perhaps also welcomed by Rudahigwa - the first Abanyiginya mwami who was not required to corule with his umugabekazi - given that Musinga's young age upon becoming mwami had rendered him particularly vulnerable to Kanjogera's influence.

\section{The Emergence of Family Planning Discourses: The First and Second Hutu Republics}

During the First and Second Hutu Republics, Christian and European values continued to become increasingly entrenched in Rwandan society, both in terms of people's

\footnotetext{
${ }^{39}$ Helen Codere, The Biography of an African Society, Rwanda 1900-60: Based on Forty-Eight Rwandan Autobiographies (Tervuren: Royal Museum for Central Africa, 1973), 138.

${ }^{40}$ Indeed, it is notable that women do not feature in Carney's comprehensive overview of Catholic politics in Rwanda prior to 1994. Carney, op. cit. (note 1). Beyond Rwanda, however, historian Richard Volks has demonstrated that Uganda-based missionaries, recognising the importance of women's spiritual leadership in communities where people worshipped Nyabingi - a likely mythical queen whose spirit could possess people, allowing them to perform miracles - encouraged practitioners to merge their beliefs with Christian theology surrounding the Virgin Mary. Richard Volk, Ghosts of Kanunga: Fertility, Secrecy and Exchange in the Great Lakes of East Africa (Suffolk: James Currey, 2009), 18.

${ }^{41}$ Kanjogera had been assigned to serve as the umugabekazi to her husband Mwami Rwabugiri's favourite son by another wife, Rutarindwa. However, soon after Rwabugiri's death in 1895, Kanjogera and her brother Kabare orchestrated a coup at Rutarindwa's new court in Rucunshu that prompted the new mwami's suicide and allowed Kanjogera to make her young son Musinga the next mwami. She subsequently arranged the massacre of Rutarindwa's supporters to ensure the court supremacy of her clan, the Abega, and took an active role in ruling the kingdom alongside her son. For more information, see Des Forges, op. cit. (note 5), 16-17; Sarah Watkins and Erin Jessee, 'Legacies of Kanjogera: Women Political Elites and the Transgression of Gender Norms in Rwanda', Journal of Eastern African Studies, 2020.
} 
everyday lives, and the laws and policies that were introduced. Presidents Kayibanda and Habyarimana were devout Catholics who publicly adhered to the Vatican's guidance, even though they also allegedly continued to practise kubandwa in private. ${ }^{42}$ In terms of family planning, they publicly supported the Catholic Church's conservative approach to 'artificial' family planning initiatives, from birth control medications to abortions.

Such policies did not necessarily reflect the presidents' personal beliefs, however. There is evidence that Kayibanda attempted to promote family planning initiatives in Rwanda aimed at reducing the number of children that couples produced: the nation's first family planning programme was established in 1962, though it was not well-documented. ${ }^{43}$ This is perhaps due to the fact that family planning rhetoric and initiatives were not particularly developed in Rwanda or internationally at this time. It could also be a reflection of the comparatively limited historiography on the Kayibanda regime compared to later periods in Rwandan history. Certainly, Kayibanda's actions suggest he was aware of the dangerous potential of overpopulation and growing land disputes between pastoralist and subsistence agriculturalists, which Vansina argues would have been a source of concern since the late nineteenth century. ${ }^{44}$ Historian Jean-Paul Kimonyo notes that some of Kayibanda's earliest policies involved expropriating land owned by the predominantly Tutsi monarchists who had been killed or forced into exile during the political violence that surrounded independence from 1959 to 1964, and redistributing it among his supporters. ${ }^{45}$ He subsequently referenced Rwanda's overpopulation as a key reason to deny the right of the resulting refugees to return to Rwanda as early as $1966 .{ }^{46}$ Kayibanda also allowed peasants to drain marshlands and claim lands previously reserved for pastures for use in subsistence agriculture, increasing the cultivable land in Rwanda by fifty per cent between 1962 and 1969 in an effort to address growing concerns about access to land among the rural Hutu majority. ${ }^{47}$ Kayibanda's efforts were ultimately unsuccessful, however. Poor land management practices and an over-investment in cash crops like coffee - the international quotas for which proved impossible to meet - resulted in major financial losses and an economic crisis that exacerbated public frustrations, particularly among educated youth. ${ }^{48}$ Kayibanda attempted to distract people from their dissatisfaction with his leadership by inciting anti-Tutsi violence in the schools and private sector in 1972, prompting tens of thousands of Tutsi to flee the country.

As a result of this instability, Habyarimana - previously Rwanda's Minister of Defense and Army Commander - wrested power from Kayibanda during the 1973 'bloodless coup' with the stated purpose of restoring peace. ${ }^{49} \mathrm{He}$ inherited a tense political climate rife with ethnic and economic tensions grounded in overpopulation and land scarcity,

\footnotetext{
42 Fieldnotes from the Presidential Palace Museum in Kigali, 2017. Peterson Tumwebaze, 'The abortion debate: "They should bear the cross!"”, The New Times, 7 November 2011, http://www.newtimes.co.rw/section/read/36 591.

43 Julie Solo, 'Family Planning in Rwanda: How a Taboo Topic Became Priority Number One', IntraHealth International June (2008), https://www.intrahealth.org/sites/ihweb/files/attachment-files/fp_in_Rwanda.pdf.

44 Vansina, op. cit. (note 2), 28.

45 Jean-Paul Kimonyo, Rwanda's Popular Genocide: A Perfect Storm (Boulder: Lynne Rienner Publishers, 2016), 37.

${ }^{46}$ Ibid., 51.

47 Kimonyo, op. cit. (note 45), 37.

48 Kimonyo, op. cit. (note 45), 37-9.

49 Though referred to as a bloodless coup, over the next two years many of Kayibanda's inner circle were executed or died in prison, while Kayibanda was allegedly starved to death. Gérard Prunier, The Rwanda Crisis: History of a Genocide (London: Hurst \& Company, 2002), 82.
} 
among other factors. Both long-standing challenges had been dramatically exacerbated over the last thirty years as a result of a combined decrease in infant mortality, and a reduction in breastfeeding and postpartum abstinence associated with the introduction of modern medicine and improved nutrition across sub-Saharan Africa. ${ }^{50}$ Indeed, scholars John May, Monique Mukamanzi and Marcel Vekemans reported that Habyarimana's regime was forced to consider introducing policies to promote family planning in the early 1970s. However, in its earliest incarnation, concerns regarding 'the high value attached to Rwandan children' and the 'strong pronatalist influence of Roman Catholicism' prompted the state to focus educating the public about natural birth control methods, such as birth spacing and abstinence, to align with the Catholic Church's position. ${ }^{51}$ Nonetheless, a survey conducted in 1984 and 1985 found that - despite the creation of a National Office of Population (ONAPO) in 1981 and efforts to sensitise Rwandans to the seriousness of overpopulation through private Protestant Church-run and national health clinics respondents continued to prioritise having as many children as possible, believing that

the utmost personal happiness is to have children in order to transmit life through them; people without children disappear from life forever. Life must be transmitted, especially to sons, as a sacred duty to family, ancestors, and lineage. In addition, children are viewed as the only security for old age. Finally, having many children give honor, prestige, and social, economic, and political strength to the parents. ${ }^{52}$

Faced with the realisation that natural family planning methods were failing to reduce overpopulation, Habyarimana created controversy in 1987 by allowing pharmacies to sell condoms and otherwise encouraging Rwandans to exercise 'individual freedom with respect to family planning'. ${ }^{53}$ He simultaneously called upon Rwanda's churches to teach more comprehensive family planning options and encourage their followers to have no more than four children. The backlash from within his ruling party and the Rwandan Catholic Church resulted in what a Belgian Senate report described as 'Catholic antiabortion radicals' - with the support of the Ministry of the Interior - raiding pharmacies that had agreed to stock condoms and destroying them. ${ }^{54}$ Simultaneously, the Rwandan Catholic Church renewed its ban on artificial family planning methods and refused to distribute contraceptives in its health centres, which in many Rwandan communities had become the primary source of medical treatment and health education. The Church's support for the Habyarimana regime began to waver, culminating in a 1990 letter that denounced Habyarimana's 'corruption, and regional and ethnic discrimination'. ${ }^{55}$ This official backlash apparently convinced Habyarimana that family planning methods were

\footnotetext{
50 John May, Monique Mukamanzi and Marcel Vekemans, 'Family Planning in Rwanda: Status and Prospects', Studies in Family Planning, 21, 1 (1990), 22.

${ }^{51}$ Ibid., 21. See also Anicet Kashamura, Famille, Sexualité et Culture: Essai sur les Moeurs Sexuelles et les Cultures des Peuples des Grands Lacs (Paris: Payot, 1973); and L. Ntezilyayo, 'Contribution à l'étude de coûtefficacité de la planification familiale au Rwanda' (unpublished PhD thesis: Institut Africain et Mauricien de Statistique et d'Economie Appliquée, 1989).

52 P. Mukamfizi, Enquête sur la Contraception Traditionelle au Rwanda (Kigali: ONAPO, 1985); cited in May et al., op. cit. (note 50), 23.

53 Previously, artificial family planning such as condoms and birth control medications were available within the country, but only via private medical facilities. May et al., op. cit. (note 50), 29, 25.

54 Cited in Stephen Childress, 'From Revolution to Ruin: A Preliminary Look at Rwanda's First Two Presidents, Grégoire Kayibanda and Juvénal Habyarimana, and their Administrations' (unpublished PhD thesis: University of Missouri-Kansas City, 2015), 375; and May et al., op. cit. (note 50).

${ }^{55}$ Ibid., 375.
} 
'anathema both as public policy and private practice', and so he did not waiver again in his public adherence to the Vatican's position on birth control. ${ }^{56}$

Throughout the First and Second Hutu Republics, women's participation in Rwanda's public sphere became increasingly limited compared to their male compatriots. It is during this period - and particularly under Habyarimana - that Rwanda earned its reputation as a deeply patriarchal society, as women were actively excluded from politics, commerce, law and education compared to their male compatriots. Genocide scholar Sara Brown notes that by 1992 the Family Code was introduced to legally recognise men as the head of Rwandan households, while in 1994 additional legal reforms prohibited Rwandan women from inheriting property or opening bank accounts without the consent of their husbands. These developments were undoubtedly part of a patriarchal backlash against the women's rights movements that had been taking shape since the 1980s across Rwanda, and 'posed a threat not just to Rwanda's patriarchal society but to its non-democratic political system as well' ${ }^{57}$

This likely resulted in increased limitations on the ideals for women's everyday behaviour as well: anthropologist Jennie Burnet notes that when she first began working in Rwanda in the early 1990s, the ideal for Rwandan women was to be reserved, submissive, respectful, silent and maternal, focusing their energies on maintaining a respectable household and raising polite children. ${ }^{58}$ Women who resisted such expectations could be publicly mocked and ostracised for transgressing Rwandan gender norms. Similar analysis by anthropologist Villia Jefremovas in the early 1990s observed that 'the language of public morality and stereotype is one weapon ... used by both men and women to interpret, manipulate, validate or negate control over labour, resources and surplus' produced by women. ${ }^{59}$

\section{Family Planning in Present-Day Rwanda}

Habyarimana's regime was brought to a sudden end by his assassination by unknown parties on 6 April 1994. His assassination occurred at the height of international efforts to end a civil war that had been initiated by an invasion by the Uganda-based Rwandan Patriotic Front (RPF) on 1 October 1990, which in turn radicalised a small cohort of Hutu Power extremists within Habyarimana's inner circle. Following Habyarimana's death, the Hutu Power-dominated interim government began mobilising youth militias to set up roadblocks around Kigali (the national capital) and kill Tutsi civilians and their supporters at the roadblocks and wherever they sought refuge. The violence spread through all areas of Rwanda that were not under RPF control. By the time the RPF formally wrested control of the country on 18 July 1994, an estimated 800000 Rwandans - most of whom were Tutsi - had been murdered in what is today referred to in official parlance as the '1994

\footnotetext{
56 Organization of African Unity, 'Rwanda, the Preventable Genocide: Report of the International Panel of Eminent Personalities to Investigate the 1994 Genocide in Rwanda', July 2000, 4:15.

57 Brown, op. cit. (note 24), 32.

58 Jennie Burnet, Genocide Lives in Us: Women, Memory and Silence in Rwanda (Madison: University of Wisconsin Press, 2012), 44-5.

59 Villia Jefremovas, 'Loose Women, Virtuous Wives and Timid Virgins: Gender and the Control of Resources in Rwanda', Canadian Journal of African Studies, 25, 3 (1991), 379.
} 
genocide against the Tutsi' ${ }^{60}$ An additional two million Rwandans fled to neighbouring Congo. ${ }^{61}$

In the genocide's aftermath, the RPF inherited the unenviable task of trying to unite a population divided, not only by ethnicity, but by political, regional, socio-economic and other tensions. With a high degree of success, they established a transitional government that prioritised rapid economic development as a key means of preventing further ethnic and political bloodshed, ensuring long-term political stability. Their efforts have included a comprehensive plan to address the persistent challenge of overpopulation through family planning, first referenced in its ambitious 'Rwanda: Vision 2020', which established a framework in 2000 for transforming 'our country into middle-income [sic.] nation in which Rwandans are healthier, educated and generally more prosperous' ${ }^{62}$ While it did not outline a family planning policy, Vision 2020 set an agenda for further development, and was quickly followed by the 2002 'Poverty Reduction Strategy Paper'. This paper highlighted family planning as a key component of its human development priority area for public action. ${ }^{63}$ It further identified Rwandan women as allies in the fight to address overpopulation, noting that the high rate of population growth 'could be substantially reduced if women had access to family planning services'. ${ }^{64}$ As part of this, the paper's authors suggested three points of action: that the government invest in improved access to reproductive health services to be provided by midwives; that they mainstream discussions of fertility as part of health information and adult literacy courses on the grounds that in some highly populated countries 'the promotion of female adult literacy has had a major impact on fertility'; and that reproductive health services be made available at the district level to ensure accessibility. ${ }^{65}$ For these reasons, the government's efforts to reduce population growth through family planning were merged early on with initiatives aimed at empowering women, promoting gender equality, reducing poverty and improving health care. ${ }^{66}$

In 2003, the National Reproductive Health Policy was published, and included family planning as one of six priority areas on the grounds that only four per cent of the nation's women were using modern family planning methods - a notable decline from the thirteen per cent who claimed to be using modern birth control methods in $1992 .{ }^{67}$ The policy's

\footnotetext{
60 This official label has proved controversial among scholars, with political scientist Scott Straus cautioning scholars against using it uncritically. See Scott Straus, 'The Limits of a Genocide Lens: Violence Against Rwandans in the 1990s', Journal of Genocide Research, 21, 4 (2019), 504-24.

${ }^{61}$ For additional information on events leading up to and during the genocide, see Alison Des Forges, Leave None to Tell the Story: Genocide in Rwanda (New York: Human Rights Watch, 1999); André Guichaoua, From War to Genocide: Criminal Politics in Rwanda, 1990-4 (Madison: University of Wisconsin Press, 2015); and Jessee op. cit. (note 15).

62 Republic of Rwanda, 'Rwanda Vision 2020', revised 2012, i, 12, http://www.minecofin.gov.rw/fileadmin/tem plates/documents/NDPR/Vision_2020_.pdf.

63 Government of Rwanda, 'Poverty Reduction Strategy Paper', June 2002, 35, http://siteresources.worldbank.o rg/INTPRS1/Resources/Country-Papers-and-JSAs/Rwanda_PRSP.pdf.

64 Ibid., 31.

65 Government of Rwanda, op. cit. (note 62), 45.

${ }^{66}$ Burnet notes that gender equality was particularly important to the RPF's approach to governance from the party's inception, which explains its prominence throughout the RPF's development policies. Jennie Burnet, 'Women Have Found Respect: Gender Quotas, Symbolic Representation and Female Empowerment in Rwanda', Politics \& Gender, 7 (2011), 310. For more information, see also Rirhandu Mageza-Barthel, Mobilizing Transnational Gender Politics in Post-Genocide Rwanda (Farnham: Ashgate, 2015).

${ }^{67}$ Republic of Rwanda, 'National Reproductive Health Policy,' July 2003, iv, 9, http://www.africanchildforum.o rg/clr/policy\%20per\%20country/rwanda/rwanda_reproductivehealth_2003_en.pdf.
} 
authors argued this decline was resulting in high rates of maternal mortality - fifteen per cent of which were then attributed to unsafe abortions aimed at ending unwanted pregnancies - and infant mortality. ${ }^{68}$ They likewise identified several shortcomings in the nation's family planning programmes that were resulting in low utilisation of family planning services, including a lack of sufficiently trained medical staff and ample medical supplies, the potential for women who wanted to use contraception to encounter significant social stigma or to feel incapable of making decisions about their reproductive health without their husbands' permission, and financial constraints, among other factors. ${ }^{69}$

This led to a series of dedicated family planning policies by Rwanda's Ministry of Health $(\mathrm{MOH})$ - the first of which was published in 2006 - that outlined comprehensive strategies for educating the public about the necessity of family planning, and ensuring that the public had access to the relevant resources to begin making informed decisions about their reproductive health and plans for building a family. ${ }^{70}$ The $\mathrm{MOH}$ began making a concerted effort to work with religious organisations, including the Catholic Church, to provide education about the full range of family planning options from which people could choose. ${ }^{71}$ Given the Catholic Church's long-standing involvement in providing healthcare to Rwanda's citizens - including currently running an estimated one-third of the country's hospitals and clinics - it has proven to be an important stakeholder in the government's efforts to promote family planning. ${ }^{72}$

But its collaboration with the Rwandan government has required a careful compromise around the topic of artificial birth control: at present, Rwanda's Catholic clinics have - at least in terms of official policy - agreed to educate patients who request contraceptives about all possible options. However, a 2016 study by global health experts Farmer et al. noted that some religious institutions were providing adherents with 'mixed messages' where family planning was concerned. ${ }^{73}$ Nonetheless, if a patient is adamant about using contraceptives, which goes against Rome's doctrine, then they should be directed to the nearest government-run mini 'health posts' ${ }^{74}$ Due to this compromise, in 2017 an estimated 28.6 per cent of Rwandan women were using modern contraceptives. ${ }^{75}$

While the government's efforts to educate the public about the importance of family planning, combined with the Catholic Church's tenuous support, has arguably countered some of the social stigma that people might face in accessing a full range of family planning options, conversations in the media and interviews with Rwandans reveal that significant challenges remain, particularly where more invasive procedures

${ }^{68} \mathrm{Ibid}$.

${ }^{69}$ Republic of Rwanda, op. cit. (note 66), 10.

${ }^{70}$ Republic of Rwanda, 'National Family Planning Policy and its Five-Year Strategies (2006-2010)', March 2006, https://www.gfmer.ch/SRH-Course-2010/national-guidelines/pdf/National-FP-policy-MOH-Rwanda-200 6.pdf. See, most recently, Government of Rwanda, 'Family Planning 2020 Commitment', 11 July 2017, https ://www.familyplanning2020.org/sites/default/files/Govt.-of-Rwanda-FP2020-Commitment-2018-Update_1.pdf.

71 Government of Rwanda, Ibid., 9.

72 Ryan Brown, 'How Rwanda's Catholic Clinics Struck a Contraception Compromise', Christian Science Monitor, 2 January 2019, https://www.csmonitor.com/World/Africa/2019/0102/How-Rwanda-s-Catholic-clinic s-struck-a-contraception-compromise.

${ }^{73}$ Didi Farmer, Leslie Berman, Grace Ryan, Lameck Habumugisha, Paulin Basinga, Cameron Nutt, Francois Kamali, Elias Ngizwenayo, Jacklin St Fleur, Peter Niyigena, Fidele Ngabo, Paul Farmer and Michael Rich, 'Motivations and Constraints to Family Planning: A Qualitative Study in Rwanda's Southern Kayonza District', Global Health, 3, 2 (2015), 249.

${ }^{74}$ Emmanuel Ntirenganya, 'Catholic Church Changes Stance on "Artificial" Family Planning Methods', The New Times, 4 September 2016, https://www.newtimes.co.rw/section/read/203226.

${ }^{75}$ Family Planning 2020, 'Rwanda: FP2020 Core Indicator Summary Sheet', 2017, http://www.track20.org/dow nload/pdf/2017\%20FP2020\%20CI\%20Handouts/english/Rwanda\%202017\%20FP2020\%20CoreIndicators.pdf. 
like vasectomies and abortions are concerned. ${ }^{76}$ In 2011, the Rwandan government announced its plan to have 700000 men voluntarily undergo vasectomies over the next three years, almost entirely covered by the national health insurance. ${ }^{77}$ In response, Sylvain Sibomana, the Secretary General of the Rwandan political opposition coalition, Forces Democratiques Unifiées (FDU-Inkingi), called for an immediate end to what he characterised as a 'mass emasculation policy' that was 'pure discrimination against the poor'. ${ }^{78}$ Another vocal critic of the RPF, Charles Kambanda, argued that the plan 'raised red flags' as the target group for the procedure was 'men who cannot pay bills for their children's upkeep', including the already marginalised rural Hutu and Twa, and Tutsi survivors of the genocide. ${ }^{79}$ While clearly motivated by the Rwandan political opposition in exile's desire to undermine international support for the RPF, such responses simultaneously speak to the broader anxieties that some Rwandan men have regarding policies that threaten to interfere with their reproductive potential. ${ }^{80}$

For example, a 2017 government report on an umuganda ('coming together in common purpose to archive an outcome') session in Kamonyi district, reported that in response to Deputy Mukakarangwa Clautilde's discussion of the benefits of family planning and negative consequences of overpopulation, a local woman named Mukanyandwi Perepetuwa testified that she not only used family planning, but she had never experienced any problems with it. ${ }^{81}$ However, Mukanyandwi added: 'family planning for men [meaning vasectomies] is still uncommon. There is still too much pressure, because most of them believe having children is a sign of wealth'. ${ }^{82}$ This suggests that the aforementioned cultural beliefs related to the value of having children in Rwandan society remain strong. Indeed, the 2012 Ministry of Health 'Family Planning Policy' claimed that such beliefs were particularly prevalent among genocide survivors who, understandably, wanted to 'replace those lost' and otherwise rebuild their lives in

\footnotetext{
76 There is evidence to suggest that in instances where religious leaders have criticised the government's family planning policies, they have faced prosecution for threatening state security. See, for example, the case of priest Emile Nsengiyumva, who was sentenced to eighteen months in prison after giving a sermon that criticised the government housing programme and family planning policies, discussed in: Freedom House, 'Rwanda: Freedom in the World', 2012, https://freedomhouse.org/report/freedom-world/2012/rwanda.

77 Edward Musoni, '700 000 Men Expected to Undergo Vasectomy', The New Times, 2 February 2011, https://w ww.newtimes.co.rw/section/read/28116.

78 Anonymous, 'Opinion: Vasectomies in Rwanda', JamboNews.net, 8 May 2012, http://www.jambonews.net/e n/news/20120508-rwanda-vasectomies-in-rwanda/.

79 Charles Kambanda, 'Rwanda: Why Sterilize the Poor?', San Francisco Bay View, 14 June 2011, https://sfbay view.com/2011/06/rwanda-why-sterilize-the-poor/.

${ }^{80}$ Interestingly, such sentiments were amplified by the far-right American print magazine, The New American. In response to the 2011 campaign, they quoted Steven Mosher of the Population Research Institute, which opposes anti-population growth initiatives, who argued that 'every single time a sterilization campaign has had a target and a timetable, it inevitably involves coercion and other human rights abuses'. Mosher linked his criticism of Rwanda's vasectomy campaign to the controversy that surrounded Rwanda's 2008 campaign to promote circumcision as a means of reducing the spread of HIV/AIDS. Michael Tennant, 'US Government Funds Rwandan Sterilization Campaign', 15 February 2011, https://www.thenewamerican.com/usnews/foreign-policy /item/1377-us-government-funds-rwandan-sterilization-campaign.

${ }^{81}$ Kamonyi District, 'Nyamiyaga: Depite Mukakarangwa yibukije abaturage ko kuboneza urubyaro ari ngombwa (Nyamiyaga: Deputy [member of Parliament] Mukakarangwa reminded citizens that family planning is very important)', Government of Rwanda, n.d., http://www.kamonyi.gov.rw/index.php?id=38\&tx_ttnews\%5B tt_news\%5D=497\&cHash=9c6e875f200ebf86a4fb6b9ab78672da. For more on umuganda - a community works programme adapted from early Rwandan history in which people came together to construct a house or undertake some similar group task, see Rwanda Governance Board, 'Umuganda', n.d., http://www.rgb.rw/index.php?id=3 7.

82 Kamonyi District, Ibid.
} 
the genocide's aftermath. ${ }^{83}$ However, I have encountered similar sentiments about the necessity of having many children among people across Rwanda, regardless of their status relative to the genocide, often associated with the proverb abana ni umutungo ('children are your wealth').

In addition to the cultural value associated with having children, a 2017 Muhabura article reported additional cultural challenges to Rwanda's family planning initiatives that were raised in Karongi district. There, several men argued that 'even though family planning is generally a good thing ... only the women should be using it'. ${ }^{84}$ One man was explicit in his reasons for rejecting vasectomies, noting 'Family planning for men? Oh my God, I can't accept that! Don't you think it's like castrating yourself? Only women should adopt family planning'. ${ }^{85}$ Another man commented 'for a man to adopt family planning, he is castrating himself ... I can't do that - family planning is for women, not for men' ${ }^{86}$ Some women in their community reinforced their position as well, with one woman stating:

Do you think I can allow my husband to adopt family planning for men? It's like castrating him. Do you think he can do well again [referring to his ability to have sex]? I can't say yes to that. I agree family planning is good for the family, but I think it should be my responsibility. I don't think it's right for my husband to do that. ${ }^{87}$

Several important cultural challenges are raised by these comments related to Rwandan gender norms, as well as misperceptions about how having a vasectomy might negatively impact a couple's sex life. Feedback from the community, which the Muhabura report claims is indicative of attitudes that are prevalent across Rwanda, suggests that a man's virility and ability to have many children are an important indicator of his masculinity and, by extension, his social status. It seems the ideals for womanhood are slightly more flexible, making it more permissible for women to use contraception and natural family planning techniques to reduce the number of children they have, though choosing not to have children remains unimaginable for most people given the associated social stigma. While women in the present still primarily gain social status by being good wives and mothers, it seems many Rwandans are now convinced that 'responsible parenthood' having only the number of children you can afford - is the best strategy for their families and the nation. ${ }^{88}$

Regarding the potential for vasectomies to negatively impact a couple's sex life, the Rwandan government is actively working to educate people about this issue. A 2017 Umubavu article reported that 5000 Rwandan men - constituting two per cent of the population - had already undergone successful vasectomies due to medical advances that had made the procedure less invasive and less likely to cause complications. ${ }^{89}$ It stressed that the procedure in no way negatively impacted a man's ability to feel or

\footnotetext{
${ }^{83}$ Government of Rwanda, 'Family Planning Policy', December 2012, 14, http://www.moh.gov.rw/fileadmin/te mplates/Docs/Rwanda-Family-Planning-Policy.pdf.

${ }^{84}$ Chief editor, 'Karongi: Ntibemera ko umugabo yaboneza urubyaro (Karongi: They do not agree that men should use family planning)', Muhabura, July 2017, http://mobile.muhabura.rw/spip.php?page=article\&id_articl $\mathrm{e}=4112$.

85 Ibid.

${ }^{86}$ Chief Editor, op. cit. (note 83).

${ }^{87}$ Chief Editor, op. cit. (note 83).

${ }^{88}$ Solo, op. cit. (note 43), 26.

${ }^{89}$ Daniel Mukeshimana, 'Ni iki kihishe inyuma yo kuba abagabo benshi mu Rwanda bamaze kwifungisha urubyaro burundu (What's the reason why so many men use permanent family planning methods)', Umubavu, 20 February 2017, http://umubavu.com/amakuru/article/Ni-iki-kihishe-inyuma-yo-kuba-abagabo-benshi-mu-Rwan da-bamaze-kwifungisha-urubyaro-burundu.
} 
respond to sexual desire, and furthermore benefited the couple by enhancing their ability to adequately support their existing children, and reducing overpopulation. The article seems to have been written with the precise intention of addressing people's misperceptions about vasectomies, and mitigating the potential for ongoing social stigma toward those who chose to undergo the procedure.

While Rwandans are arguably becoming more accepting of vasectomies, abortion is still heavily stigmatised for both religious and cultural reasons. Prior to 2012, Rwanda had a highly restrictive abortion law that only permitted the procedure in instances where the pregnant woman could find two physicians who would certify that she needed the procedure to save her life due to high risk of complications. ${ }^{90}$ Women who did not demonstrate this risk, but were faced with unwanted pregnancies, were thus forced to either give birth or seek unsafe abortions that carried a complication rate of forty-four per cent. Complication rates were particularly high among rural women who induced the abortion themselves (sixty-seven per cent) or who sought support from a 'traditional healer' (sixtyone per cent). ${ }^{91}$ Simultaneously, a study by the community-based organisation, Rwandan Youth Action Movement, amplified the voices of young, mostly rural, Rwandan women who had been imprisoned for having abortions - many of which were the outcome of pregnancies resulting from rape - to demonstrate the need for immediate legal reform. ${ }^{92}$ Particularly concerning, these studies demonstrated that rural women who did not have the resources to procure safe abortions outside Rwanda were at heightened risk of both complications and prosecution.

In 2012, the Rwandan government decided to expand the legal grounds for abortion to includes instances where the woman's pregnancy resulted from rape, incest and/or forced marriage, or where significant fetal impairment was detected. This required the woman to obtain a court order, with support from her physician, prior to undergoing an abortion a process that could take weeks and, in some instances, too late for the woman to have the requested abortion. ${ }^{93}$ In 2018, a further revision was proposed that, if successful, will allow a woman and her doctor to decide whether an abortion is necessary without requiring a court order and without the potential for criminal charges where the pregnancy resulted from rape, incest and/or forced marriage, or where significant fetal impairment was detected. ${ }^{94}$

The revised law, while an improvement in terms of women's rights, has encountered significant challenges to its implementation. The Rwandan Catholic Church's leadership held a press conference shortly after the revised abortion law was announced, condemning it as a 'shame upon the country'. ${ }^{95}$ Bishop Smaragdi Mbonyintege argued that 'anytime you kill a baby in its mother's womb is always killing a person', ${ }^{96}$ and he called upon

90 Guttmacher Institute, 'Abortion in Rwanda', April 2013, https://www.guttmacher.org/fact-sheet/abortion-rwa nda.

91 Ibid

92 Chantal Umuhoza, Barbara Oosters, Miranda van Reeuwijk and Ine Vanwesenbeeck, 'Advocating for Safe Abortion in Rwanda: How Young People and the Personal Stories of Young Women in Prison Brought About Change', Reproductive Health Matters, 21, 41 (2013), 49-56.

93 Rodrigue Rwirahira, 'Rwanda's Proposed Abortion Amendment Takes Procedure Out of the Courts', News Deeply, 22 January 2018, https://www.newsdeeply.com/womenandgirls/articles/2018/01/22/rwandas-proposedabortion-amendment-takes-procedure-out-of-the-courts.

94 James Karuhanga, 'Government drafts guidelines on abortion', The New Times, 11 October 2018, https://ww w.newtimes.co.rw/news/government-drafts-guidelines-abortion.

95 BBC Gahuza, 'Abayobozi b'amadini mu Rwanda bamaganye gukuramo inda (Church leaders in Rwanda are fighting against the new abortion law)', 9 April 2012, https://www.bbc.com/gahuza/amakuru/2012/04/120409_r wanda_religious_abotion.

96 Ibid. 
the Rwandan government to work with the Catholic Church in 'preventing unwanted pregnancies'. ${ }^{97}$ The Church's leadership further called for a referendum on the revised law, noting that their followers and those of other Christian faiths would likely reject it as it did not align with their belief that only God should be permitted to take a life. ${ }^{98}$ There is evidence to suggest they are correct in this assessment: with an estimated ninety-three per cent of Rwandans identifying as Christian, broadly speaking, it is possible that the majority of voters would uphold the view that abortion is murder and constitutes a crime, rather than a basic human right that should be extended to women, albeit on a limited basis. ${ }^{99}$ This perspective was certainly present in the casual conversations I had with Rwandans after the revised law was announced in 2012.

And yet, despite this controversy, the Rwandan government has continued to work toward implementing the revised law in accordance with its broader efforts to respect women's rights. In addition to sensitising the public to the details of the revised law and making abortions more affordable through national health care, on 5 April 2019 President Paul Kagame pardoned 367 women who had been convicted of the crimes of abortion, complicity in abortion and infanticide - a decision that was met with accolades from international human rights groups who hope it is a gradual step toward decriminalising abortions entirely. ${ }^{100}$ The Catholic Church has remained relatively silent in the media about these pardons. However, six days after the announcement, the government newspaper The New Times published an opinion piece that, in addition to condemning the Catholic Church for its complicity in the 1994 genocide and siding with the perpetrators, criticises its 'endless petitions against the 30 per cent women minimum quota in governance, petitions against legal abortion and any other progressive policies ever adopted in Rwanda', suggesting that tensions between the Rwandan government and the Rwandan Catholic Church remain high. ${ }^{101}$

Beyond these challenges around more invasive family planning techniques, unmarried men and women in the present may also continue to face social stigma for seeking birth control medication and prophylactics. For example, a nurse at a Catholic health centre recently commented that she only received requests from couples, which she explained by noting that 'if you don't have a husband, what do you need family planning for? ... You have nothing to plan'. ${ }^{102}$ In conversations with Rwandan youth since 2007, people have frequently commented upon the prevalence of this kind of attitude among Rwandans, including medical professionals, religious leaders and family members. While Kabakobwa is no longer used to punish unmarried women who become pregnant outside marriage, young men seem to now share the social stigma of impregnating a girlfriend. Indeed, youth seem keenly aware of the social stigma they will be subjected to if they fail to abstain from sex before marriage, though, as in many nations, this does not make practising abstinence any easier.

\footnotetext{
97 Igihe, 'Perezida Kagame yaganiriye n'abanyamadini ku kibazo cyo gukuramo inda (President Kagame talked to church leaders about abortion)', 20 April 2012, http://www.igihe.com/amakuru/u-rwanda/perezida-kagame-y aganiriye-n-abanyamadini-ku-bijyanye-n-ikibazo-cyo-gukuramo-inda.

98 Ibid.

${ }^{99}$ Central Intelligence Agency, op. cit. (note 6).

100 Samuel Okiror, 'Paul Kagame Orders Release of Women and Girls Jailed over Abortion in Rwanda', The Guardian, 5 April 2019, https://www.theguardian.com/global-development/2019/apr/05/paul-kagame-orders-re lease-of-women-and-girls-jailed-over-abortion-in-rwanda.

101 Gatete Nyiringabo Ruhumuliza, 'False Prophets in the Catholic Church', The New Times, 11 April 2019, htt ps://www.newtimes.co.rw/opinions/false-prophets-catholic-church.

102 Brown, op. cit. (note 71).
} 


\section{Conclusion}

While it is evident that Rwandan gender norms have changed over the twentieth and twenty-first centuries in response to transformations in Rwanda's political climate and religious foundations, attitudes toward family planning are only recently beginning to evolve. The sources discussed in this article suggest that the introduction of Catholicism and related European values had a significant impact on women's political and spiritual authority. However, the challenges that modern Rwanda faces in promoting gender equality and family planning cannot be solely attributed to this religious transformation. The ibitekerezo and interviews discussed above reveal the immense social value that Rwandans associate with having children. Furthermore, they suggest that Rwandans have historically endured significant social pressure - perhaps dating back to the origins of the Nyiginya kingdom - to have as many children as possible. This social pressure is undoubtedly complicated by Catholic religious restrictions in some instances - particularly where artificial birth control methods are concerned - but its origins are rooted in early Rwandan culture and history.

Nonetheless, the immense value associated with having many children poses a challenge to the current Rwandan government's efforts to promote family planning to address the challenges the nation faces as one of the world's most densely populated nations. As the government strives to mainstream gender equality throughout its political platform, it is demonstrating notable achievements in terms of women's participation in politics. At present, Rwanda leads the world in terms of the number of women holding higher offices in government: in 2008 Rwanda became the first country in the world to elect a majoritywomen parliament, while in the 2013 parliamentary elections these results increased, with women claiming sixty-four per cent of the available seats. ${ }^{103}$

There is controversy regarding the extent to which current gender equality and reconciliation initiatives are improving the everyday lives of rural Rwandan women, most notably led by sociologist Marie Berry and political scientist Susan Thomson. ${ }^{104}$ They have argued that Rwandan women political elites are better positioned to take advantage of the RPF's gender equality reforms than their rural counterparts - an observation that holds in many contexts beyond Rwanda as well. However, with regard to family planning, recent estimates suggest that the government's efforts to mainstream women as valued partners in the push to combat population growth is meeting with some success: a 2016 report by the scholars affiliated with the National University of Rwanda found that the rate of contraception use by women had increased to fifty-two per cent over the last five years, which the study attributed to the government's efforts to educate the public and improve public access to health care, among other achievements. ${ }^{105}$ It remains to be seen whether Rwandans will respond similarly positively to efforts to sensitise them to the additional benefits of vasectomies or the need to decriminalise abortions, even in limited circumstances, given the power of long-standing cultural values and more recent religious pressures.

\footnotetext{
103 Brown, op. cit. (note 24), 230.

104 See for example, Marie Berry, "“There is no Hope to Get a Better Life": How Rwanda's Remarkable Twodecade March from Genocide has Left Women Behind', Foreign Policy, 7 April 2014, http://foreignpolicy.com /2014/04/07/there-is-no-hope-to-get-a-better-life/; and Susan Thomson, 'Rwanda: Visible Progress yet Power is Still a Male Preserve', The World Today, 71, 2 (2015), 20-1.

105 Dieudonne Muhoza, Pierre Rutayisire and Aline Umubyeyi, 'Measuring the Success of Family Planning Initiatives in Rwanda: A Multivariate Decomposition Analysis', Journal of Population Research, (2016), 361-77.
} 